\title{
Biochemical Responses of Elevated Level of Fluoride in Nutrient Medium on Wheat and Barley
}

\author{
Uday Pratap Singh*, Bhudeo Rana Yashu, Sanjay Kumar and J.P. Srivastava \\ Department of Plant Physiology, Institute of Agricultural Sciences., Banaras Hindu \\ University, Varanasi, India \\ *Corresponding author
}

\section{Keywords}

Fluoride toxicity, Morphological parameters, Sugar content, Starch content, Amino acids content, Protein content, MDA content

Article Info

Accepted:

25 January 2020

Available Online:

10 February 2020
A B S T R A C T

The present study response of wheat and barley to fluoride toxicity.40 days old hydroponically grown plants were exposed to different levels of fluoride stress by supplementing normal Hoagland's solution with 100 ppm $\left(\mathrm{T}_{1}\right)$ and $200 \mathrm{ppm}$ fluoride $\left(\mathrm{T}_{2}\right)$ using $\mathrm{NaF}$. Observations were recorded after 25 days of imposing fluoride treatments. In wheat and barley starch content in leaves increased with increased fluoride concentration in root zone. Soluble sugar content followed a decline trend in wheat but in barley it creased up to $\mathrm{T}_{1}$ level and then declined. In both crops soluble protein content declined but proline and free amino acid contents increased with increased fluoride concentration in root. In wheat malondialdehyde (MDA) content decreased significant in plants under $\mathrm{T}_{1}$ treatment, but further increased markedly at $200 \mathrm{ppm}$ of $\mathrm{NaF}$. In barley MDA content increased progressively and significantly as the level of $\mathrm{NaF}$ increased. As compared to barley, $100 \mathrm{ppm}$ fluoride was lesser toxic to wheat for measured parameters while at $200 \mathrm{ppm}$ both crops were equally sensitive to fluoride toxicity. It is opined that MDA content may be taken as a parameter to identify fluoride toxicity tolerant and sensitive crops.

\section{Introduction}

Fluorine is one of the most common elements in the natural environment. It is the $13^{\text {th }}$ most abundant element in the earth crust (Loganathan et al., 2011). The uptake of fluoride by plants from the substrate is typically low because soil-borne fluoride most frequently occurs in a form unavailable to plants; hence plants absorb considerable amounts of this element under natural conditions (Snioszek et al., 2009). Fluorides are common phytotoxic air and soil pollutant (Guderian, 2012). However, in soils polluted with fluoride; plants may take up its excessive quantities. Soils exposed to large emission of 
fluoride tend to accumulate it, which eventually has an unfavorable impact on agricultural production. The negative effect of fluoride on plants is manifested, for example, by chlorosis (yellowing) and necrosis of leaves as well as a decrease in content of chlorophyll in leaves. The end result of which is the inhibited growth of plant and less biomass production (Ram et al., 2014). The influence of fluoride on plants ought to be viewed from two angles. On one hand, the effect of this element contained in industrial gases and dusts and on the other hand, the effect of fluoride absorbed by the root system of plant (Sabal et al., 2006). Fluoride toxicity affects physiological and biochemical parameter in plant viz. seed germination (Farooq and Bara, 2010) and growth, nutrient uptake, photosynthesis, respiration, yield and yield attributes (Sodani et al., 2018). Fluoride in higher concentration is also injurious to animals and human beings (Choubisa and Choubisa, 2016). Earlier it was thought that the chief source to fluoride toxicity in human beings is through drinking water, but now it is well documented that plants contribute significantly to fluoride toxicity in organisms (Choubisa and Choubisa, 2010). Crop and crop varieties are reported to respond differently to increased fluoride concentration in soil and accumulate differential amounts of fluoride in their vegetative and reproductive parts (Mondal and Gupta, 2015). Barley is reported to be more sensitive to fluoride toxicity than wheat (Singh et al., 2017; Arya and Rao, 1978). Toxicity of fluoride is expected to intensify with increased atmospheric pollution and depleting soil water table. It is, therefore, expected that in days to come hazard of fluoride will increases. Therefore, it is essential to identify differential responses of crops and their genotypes to fluoride toxicity and the effect of elevated levels of fluoride on biochemical processes of plants so that parameters associated with fluoride toxicity may be visualized and crops genotypes resistant to fluoride toxicity may be identified/developed.

\section{Materials and Methods}

A hydroponic experiment was carried out in the Net House of the Agricultural Farm of the Institute of Agricultural Sciences, Banaras Hindu University, Varanasi, situated at $25^{\circ} 18^{\prime}$ $\mathrm{N}$ latitude, $83^{\circ} 3^{\prime} \mathrm{E}$ longitude and at an altitude of 75.7 meter above the mean sea level during rabi (winter season) 2016-17 taking wheat (HUW-234) and barley (EMBSN-34) genotypes. Seeds were germinated on Petri dishes in an incubator for 3 days at $28 \pm 1^{\circ} \mathrm{C}$. Plastic containers $(18 \times 18 \times 9 \mathrm{~cm})$ were taken and filled with $21 \mathrm{~L}$ distilled water. Containers were covered with steriofoam sheet in such a way that it was 1 $\mathrm{cm}$ above the upper level of water in the containers. Steriofoam sheets were having holes ( $2 \mathrm{~cm}$ diameter) at a distance of $5 \mathrm{~cm}$. Three days old seedlings of uniform growth were selected carefully from Petri dishes and planted in each hole on steriofoam sheet with the support of sterilized cotton plug. For three days seedlings were grown on distilled water and then supplied with N/2 Hoagland's (Epstein, 1972) nutrient solution for the next 3 days. Thereafter, it was replaced by NHoagland's solution. Plants were allowed to grow in N-Hoagland's solution up to the age of 40 days. During this period Hoagland's solution was replaced at an interval of every three days. Trays were grouped into 3 sets and after 40 days supplemented with $\mathrm{N}$-Hoagland $\left(\mathrm{T}_{0}\right)$, N-Hoagland+100ppm fluoride $\left(\mathrm{T}_{1}\right)$ and $\mathrm{N}$-Hoagland + 200ppm fluoride $\left(\mathrm{T}_{2}\right)$ using $\mathrm{NaF}$. Observations pertaining to soluble sugar (Dubois et al., 1956), starch (Dubois et al., 1956), protein (Kruger, 2002), amino acids (Dubois et al., 1956), proline (Bates et al., 1973) and malondialdehyde (Heath and Packer, 1968) contents were recorded after 25 days of imposing $\mathrm{NaF}$ treatment on first fully expanded leaf from top. At the time of 
observation, total plant age was 65 days. All observations were recorded in three replications and mean values were calculated. Data were analyzed following completely randomized design. Critical difference (CD) values were calculated at $1 \%$ level.

\section{Results and Discussion}

In wheat soluble sugar content though decreased with increased leave of fluoride in the root zone (Table 1) but differences between treatments were not significant. Starch content increased significantly, i.e., from $29.36 \mathrm{mgg}^{-1}$ fresh weight in control $\left(\mathrm{T}_{0}\right)$ to $43.822 \mathrm{mgg}^{-1}$ fresh weight in $\mathrm{T}_{1}$ and 45.760 $\mathrm{mgg}^{-1}$ fresh weight in plant under $\mathrm{T}_{2}$ treatment The maximum protein content $\left(0.136 \mathrm{mgg}^{-1}\right.$ fresh weight) was observed in $\mathrm{T}_{0}$ plants and the minimum $\left(0.103 \mathrm{mgg}^{-1}\right.$ fresh weight $)$ in plant under $\mathrm{T}_{2}$ treatment (Table 1). Nevertheless, differences were significant between $\mathrm{T}_{0}$ and $\mathrm{T}_{2}$. In this crop, as compared to $\mathrm{T}_{0}$, proline content though increased in plants under $T_{1}$ treatment, but difference was not significant. However, in plant under $T_{2}$ treatment proline content of $0.346 \mathrm{mgg}^{-1}$ fresh weight was significant high than those in $\mathrm{T}_{0}$ plants (Table 1). Free amino acids content in leaves increased under $\mathrm{NaF}$ treatments (Table1).Nevertheless, difference between treatments did not differ significantly. The MDA content, as compared to control $\left(\mathrm{T}_{0}\right)$, decreased markedlyin plants under $T_{1}$ treatment in wheat, but further increased significantly in plant treated with $200 \mathrm{ppm}$ fluoride (Table 1).

In barley, as compared to $\mathrm{T}_{0}$ plants, soluble sugars increased significantly in plant under fluoride treatment and the increment was of higher magnitude in plants under $\mathrm{T}_{1}$ treatment than in plants underT ${ }_{2}$ (Table 2). Starch content also increased significantly with added doses of $\mathrm{NaF}$ in the Hoagland's solution (Table 2). Protein content, as compare to $\mathrm{T}_{0}$, decreased in plant as the level of fluoride increased in the nutrient medium (Table 2). Proline content, as compared to $\mathrm{T}_{0}$, increased in plants under $\mathrm{T}_{1}$ treatment which further declined in plant under $\mathrm{T}_{2}$ treatment (Table 2).In this crop, MDA content increased significantly as the level of $\mathrm{NaF}$ increased in the Hoagland's solution.

Table.1 Effect of different levels of sodium fluoride treatment on soluble sugar, starch, proline, protein, free amino acids ( $\mathrm{mg} \mathrm{g}^{-1}$ fresh weight) and MDA ( $\mathrm{nM} \mathrm{g}^{-1}$ fresh weight) contents in wheat (HUW-234)

\begin{tabular}{|c|c|c|c|c|c|c|c|}
\hline S.No. & Treatments* & $\begin{array}{c}\text { Soluble } \\
\text { sugar }\end{array}$ & Starch & Protein & Proline & MDA & $\begin{array}{c}\text { Free amino } \\
\text { acids }\end{array}$ \\
\hline 1. & $\mathrm{T}_{0}$ & 13.668 & 29.360 & 0.136 & 0.242 & 14.849 & 0.153 \\
\hline 2. & $\mathrm{T}_{1}$ & 12.105 & 43.822 & 0.123 & 0.336 & 9.548 & 0.167 \\
\hline 3. & $\mathrm{T}_{2}$ & 11.472 & 45.780 & 0.103 & 0.346 & 27.591 & 0.192 \\
\hline & SEm \pm & 1.374 & 3.549 & 0.010 & 0.035 & 0.585 & 0.027 \\
\hline & C.D. at $1 \%$ & 4.758 & 12.282 & 0.036 & 0.119 & 2.025 & 0.092 \\
\hline
\end{tabular}

$* \mathrm{~T}_{0}=$ Normal Hoagland $\left(\right.$ Control), $\mathrm{T}_{1}=$ Normal Hoagland $+100 \mathrm{ppm}$ fluoride, $\mathrm{T}_{2}=$ Normal Hoagland $+200 \mathrm{ppm}$ fluoride

Plant was imposed with above treatments after 40 days of growth. Observation was taken after 25 days of imposing fluoride treatments (at observation total plant age 65 days). 
Table.2 Effect of different levels of sodium fluoride treatment on soluble sugar, starch, proline, protein, free amino acids ( $\mathrm{mg} \mathrm{g}^{-1}$ fresh weight) and MDA ( $\mathrm{nM} \mathrm{g}^{-1}$ fresh weight) in barley

(EMBSM)

\begin{tabular}{|c|c|c|c|c|c|c|c|}
\hline S.No. & Treatments* & $\begin{array}{c}\text { Soluble } \\
\text { sugar }\end{array}$ & Starch & Protein & Proline & MDA & $\begin{array}{c}\text { Free amino } \\
\text { acids }\end{array}$ \\
\hline $\mathbf{1 .}$ & $\mathrm{T}_{0}$ & 14.843 & 29.360 & 0.118 & 0.325 & 21.505 & 0.853 \\
\hline $\mathbf{2 .}$ & $\mathrm{T}_{1}$ & 24.358 & 43.823 & 0.085 & 0.594 & 32.903 & 0.409 \\
\hline $\mathbf{3 .}$ & $\mathrm{T}_{2}$ & 18.022 & 45.780 & 0.078 & 0.340 & 42.043 & 0.056 \\
\hline & SEm \pm & 1.158 & 3.549 & 0.015 & 0.045 & 2.258 & 0.130 \\
\hline & C.D at $1 \%$ & 4.009 & 12.282 & 0.054 & 0.155 & 7.811 & 0.450 \\
\hline
\end{tabular}

$* \mathrm{~T}_{0}=$ Normal Hoagland (Control), $\mathrm{T}_{1}=$ Normal Hoagland $+100 \mathrm{ppm}$ fluoride, $\mathrm{T}_{2}=$ Normal Hoagland $+200 \mathrm{ppm}$ fluoridePlant was imposed with above treatments after 40 days of growth. Observation were taken after 25 days of imposing fluoride treatments (at observation total plant age 65 days)

Table.3 Per cent increase (+) or decrease (-) in soluble sugar, starch, proline, protein, free amino acids and MDA contents in plants under $\mathrm{T}_{1}$ and $\mathrm{T}_{2}$ treatments over $\mathrm{T}_{0}$ in wheat and barley

\begin{tabular}{|c|c|c|c|c|c|c|c|}
\hline Crop & Treatments* & $\begin{array}{c}\text { Soluble } \\
\text { sugars }\end{array}$ & Starch & Protein & Proline & MDA & $\begin{array}{c}\text { Free amino } \\
\text { acids }\end{array}$ \\
\hline \multirow{2}{*}{ Wheat } & $\mathrm{T}_{1}$ & 11.42 & 49.25 & 9.55 & 38.84 & 37.71 & 9.15 \\
\cline { 2 - 8 } Barley & $\mathrm{T}_{2}$ & 16.03 & 55.92 & 24.26 & 42.97 & 85.86 & 25.49 \\
\hline & $\mathrm{T}_{1}$ & 64.08 & 46.34 & 27.96 & 82.76 & 53.03 & 52.05 \\
\hline & $\mathrm{T}_{2}$ & 21.42 & 54.78 & 33.89 & 4.61 & 95.53 & 93.43 \\
\hline
\end{tabular}

$* \mathrm{~T}_{0}=$ Normal Hoagland (Control), $\mathrm{T}_{1}=$ Normal Hoagland $+100 \mathrm{ppm}$ fluoride, $\mathrm{T}_{2}=$ Normal Hoagland $+200 \mathrm{ppm}$ fluoride

The maximum amount of MDA was found in leaves of those plants which were under $T_{2}$ treatment (Table 2).Free amino acids content in barley reduced significantly as the amount of $\mathrm{NaF}$ in Hoagland's solution increased progressively (Table 2 ).

Phytotoxicity due to $\mathrm{NaF}$ is one of the severe ecological problems in the world. Presence of fluoride in soil or irrigation water causes an array of physiological and biochemical changes in plants, affecting plant growth and development and may lead to a drastic reduction in economic yield (Szostek and Ciecko, 2017). Present investigation indicated that increased fluoride level in root zone caused derangement in the levels of soluble sugars, starch, protein, proline and free amino acids contents in leaves of wheat at barley.
Such observations have been reported by others (Kumar, 2000; Murray and Wilson, 2014; Panda, 2015). A central role of sugars depends not only on direct involvement in the synthesis of other compound and production of energy but also on stabilization of membrane action such as regulators of gene expression and as signalling molecules (Mohammadkhani and Heidari, 2008). Phosphoglucomutase, a key enzyme in the sucrose biosynthesis, is reported to be very sensitive to fluoride toxicity, which results in inhibition of sucrose biosynthesis in plants (Yang and Miller. 1963). Soluble sugar content proved to be a better marker for selecting improvement of $\mathrm{F}$ toxicity tolerance in wheat and barley (Gadi et al., 2012). In present investigation, in wheat crop, soluble sugar content as compare to control plant $\left(\mathrm{T}_{0}\right)$ 
decreased under both $T_{1}$ and $T_{2}$ treatments which suggested the inhibition of sucrose synthesis by $\mathrm{NaF}$.

In barley at $\mathrm{T}_{1}$ level of $\mathrm{F}$, soluble sugar content increases while at $\mathrm{T}_{2}$ level of $\mathrm{F}$ it decreased (Table 3) which indicated that as compared to wheat soluble sugar biosynthesis in barley is lesser sensitive to fluoride toxicity. Literature is available to indicate variable trend in soluble sugar level under fluoride toxicity in plants (Greenway and Munns, 1980). Increased starch content in wheat and barley under fluoride toxicity indicated that starch breakdown is suppressed by fluoride. It is reported that fluoride inhibits activity of $\alpha$-amylase (Sethy and Ghosh, 2013). In the presence of fluoride activity of $\alpha$-amylase declines due to binding of calcium with fluoride making calcium non-available. Probably this is the major cause for high starch content in plants supplemented with F.

Proline levels in plants may cause augmentation of antioxidant response, as proline has been shown to maintain protein integrity and enhance the activities of different enzymes (Ahmad et al., 2010). ROS scavenging activity of proline has been suggested as it acts as a singlet oxygen quencher (Gadi, 2016). It is well known that proline plays a key role in conferring tolerance to the plants against various abiotic stresses (Weinstein and Davison, 2004; Wang et al., 2004). Proline content increased under $\mathrm{T}_{1}$ and $\mathrm{T}_{2}$ in wheat in increasing order but in barley significant increment $(82.76 \%)$ was observed in plants under $\mathrm{T}_{1}$ treatment and it declined $(4.16 \%)$ in plants under $\mathrm{T}_{2}$ treatment, which is in agreement with other work (Datta et al., 2012).

Proteins, being one of the important organic nitrogenous constituents of plants, play a important role in the compensatory metabolism of a plant species during $F$ stress conditions. In wheat and barley content of soluble protein was higher in the control plants which decreased to 9.55 and $24.26 \%$ in wheat and 27.96 and $33.89 \%$ in barley with increased $\mathrm{NaF}$ concentrations from 100 to 200 ppm, respectively. Though at these $F$ treatments free amino acid content increased concomitantly $\quad(9.15$ and $25.49 \%$, respectively) in wheat but declined significantly in barley (Table 3). Increased free amino acid content in fluoride supplemented plants is, therefore, concluded due to increased hydrolysis of proteins. It is also possible that incorporation of free amino acids into protein is decreased. It is documented that fluoride has toxic effects on protein synthesis; as a result, as compared to normal plant fluoride stressed plants have lower protein content (Gadi, 2016). Fluoride is reported to inhibit chain elongation of polypeptides (Rao et al., 2013). Significant increase in free amino acid content and reduction in protein content in barley than in wheat indicated that protein synthesis, is more sensitive in barley than in wheat to fluoride toxicity. Reference is also available to indicate that fluoride toxicity leads to increased tissue protein content (Asthir and Tak, 2017).

The concentration of lipid peroxidation products was determined in roots and shoots in term of content of thiobarbituric acid reactive substances (TBARS) and this is widely used as marker for evaluating oxidative stress which varies in responses to abiotic stresses (Bansal and Srivastava, 2012; Mirzaee et al., 2017). Active oxygen metabolism plays a very important role in plant defence and tolerance to abiotic stress (Mittler, 2002). In abiotic stresses conditions such as drought, high salinity, extreme temperatures, high irradiance, UV light, nutrient deficiency, and air pollution, the production of reactive oxygen species (ROS) viz. singlet oxygen $\left(\mathrm{O}_{2}\right)$, superoxide $\left(\mathrm{O}_{2}^{-}\right)$, hydrogen peroxide $\left(\mathrm{H}_{2} \mathrm{O}_{2}\right)$, and hydroxyl radicals $\left(\mathrm{OH}^{-}\right)$takes place in plant cells. 
Within a certain range ROS levels do not damage the plants but excessive ROS accumulation results in oxidative damage. Oxidative damage to membranes is quantified in terms of malondialdehyde (MDA) content. The MDA contain is considered as an index of extent of membrane injury due to stress (Yamazoe, 1962). Under fluoride stress, it is reported that the level of ROS is increased (Saini et al., 2013; Wang et al., 1991). Derangement in proper functioning of plasma membrane by elevated level of fluoride has been reported in plants (Rakowski and Zwiazek, 1992). Mulberry genotypes with low MDA content under fluoride stress have been reported to tolerant higher levels of fluorid (Kumar et al., 2013). Increased MDA content under fluoride toxicity has been observed in present investigation. At $T_{1}$ treatment MDA contain decreased in wheat which indicated that this treatment of sodium fluoride was not lethal to bio-membranes in wheat but at $\mathrm{T}_{2}$ the MDA increased to $85.86 \%$. It indicated that $200 \mathrm{ppm}$ fluoride is lethal to wheat (Table 3). In barley at both sodium fluoride treatments MDA contain increased, indicated that in this crop even $T_{1}$ treatment is lethal to bio-membranes.

It is concluded that in wheat and barley fluoride toxicity resulted in derangement in soluble sugars, starch, protein, free amino acid, proline and MDA contents. As compared to barley, $100 \mathrm{ppm}$ fluoride was lesser toxic to these parameters while at 200 ppm both crops were equally sensitive to fluoride toxicity. In wheat as well as in barley MDA content increased under fluoride toxicity therefore it may be taken as a parameter to identify fluoride tolerate crop.

\section{References}

Ahmad, P., Jaleel C A, Salem M A, Nabi G and Sharma S. (2010). Roles of enzymatic and nonenzymatic antioxidants in plants during abiotic stress. Critical reviews in biotechnology, 30(3), 161-175.

Arya K P. and Rao D N. (1978). Cytogenetical Response of Pisum sativum to fluoride toxicity. Today's and Tomorrow's Printers and Publishers, Progress in Ecology, New Delhi. 81: 3-102.

Asthir, B. and Tak. (2017). Fluoride-induced changes in carbon and nitrogen metabolism in two contrasting cultivars of Triticum aestivum L. Fluoride50(3), 334342.

Bansal, R. and Srivastava J P.(2012). Antioxidative defense system in pigeonpea roots under waterlogging stress, Acta Physiologiae Plantarum, 34:515-522.

Bates, L S., Waldren R P. and Teare I D. (1973). A rapid method of proline estimation in water stressed plants. Plant and Soil 1973; 39: 205-207.

Choubisa, S L. and Choubisa D. (2016). Status of industrial fluoride pollution and its diverse adverse health effects in man and domestic animals in India. Environ Sci Pollut Res 23:7244-7254.

Datta, J K., Maitra A., Mondal , N K. and Banerjee A. (2012). Studies on the impact of fluoride toxicity on germination and seedling growth of gram seed (Cicer arietinum L. cv. Anuradha), Journal of Stress Physiology and Biochemistry. 8(1): 44.

Dubois M, Gilles K, Hamilton J K, Smith F. (1956). Calorimetric method for determination of sugar and related substances, Annual Chemistry 28: 350356.

Epstein E. (1972). Mineral nutrition of plants: Principles and perspectives. John Wiley and Sons, New York.

Farooq, M., Bara S M A, Wahid A and Ahamad N. (2010). Changes in nutrient homeostasis and reserve metabolism during rice seed priming: consequences for seedling emergence and growth. Agri Sci China 9: 191-98.

Gadi, B R., Verma P. and Amra R.(2012). Influence of $\mathrm{NaF}$ on seed germination, membrane stability and some 
Biochemicals content in Vigna seedlings, Journal of Chemical, Biological and Physical Sciences May-July (3): 13711378.

Gadi B R. (2016). Effect of fluoride on metabolic patterns and nitrate reductase activity in Ziziphus seedlings. Journal of global biosciences 5(2):3694-3698.

Gadi B R.(2016). Effect of fluoride on metabolic patterns and nitrate reductase activity in Ziziphus seedlings, Journal of Global biosciences. 5, 3694-98.

Gautam, R. and Bhardwaj, N. (2010). Bioaccumulation of fluoride in different plant parts of Hordeum vulgare (barley) var. rd-2683 from irrigation water, Fluoride, 43(1), 57-60.

Greenway, H. and Munns, R A. (1980). Mechanism of salt tolerance in non holophytes, Annual Review Plant Physiology 69: 514.

Guderian, R. (2012). Air pollution phytotoxicity of acidic gases and its significance in air pollution control (Vol. 22). Springer Science and Business Media.

Heath, R. L. and Packer L. (1968). Photoperoxidation in isolated chloroplasts I. Kinetics and stoichiometry of fatty acid peroxidation, Biochemistry 125: 189-198.

Kruger, N. J. (2002). The Bradford method for protein quantitation. In The protein protocols handbook (pp. 15-21). Humana Press.

Kumar, A. (2000). Effect of sodium fluoride toxicity on the growth and productivity of pea, barley and tomato. C.C.C. University, Meerut U.P. (Ph.D. thesis).

Kumar, K. A. Varaprasad P. and Rao A V. (2009). Effect of fluoride on catalase, guiacol peroxidase and ascorbate oxidase activities in two verities of mulberry leaves (Morus alba L.). Res J Earth Sci. 1(2): 69-73.

Loganathan, P., Hedley M, Wallace G and Roberts A. (2001). Fluoride accumulation in pasture forages and soils following long-term applications of phosphorus fertilizers. Environ. Pollut. 115(2):27582.
Mirzaee, M., Moieni, A and Ghanati F. (2013). Effects of drought stress on the lipid peroxidation and antioxidant enzyme activities in two canola (Brassica napus L.) cultivars. Journal of Agricultural Science and Technology, 15(3): 593-602.

Mittler R. (2002). Oxidative stress, antioxidants and stress tolerance. Trends in Plant Science; 7(9): 405-10.

Mohammadkhani N., (2008). Heidari R. Drought-induced accumulation of soluble sugars and proline in two maize varieties. World Appl. Sci. J.; (3): 448-53.

Mondal D, Gupta S. (2015). Fluoride hydrogeochemistry in alluvial aquifer: an implication to chemical weathering and ion-exchange phenomena. Environmental Earth Sciences, 73(7), 3537-3554.

Murray F, Wilson S. (2012). The joint action of sulphur dioxide and hydrogen fluoride on the yield and quality of wheat and barley. Environ. Pollut., 55:239-249.

Panda D. (2015). Fluoride toxicity stress: physiological and biochemical consequences on plants. Int J Bioresour Environ Agric Sci, 1, 70-84.23.

Panse, V.G. and Sukhatme, P.V. (1976). Statistical methods for research workers, ICAR, New Delhi. 220-40.

Rakowski K J, Zwiazek J. J. Early effects of hydrogen fluoride on water relations, photosynthesis and membrane integrity in eastern white pine (Pinetrobus) seedlings, Environmental and Experimental Botany 1992; 33: 377-382.

Ram A, Verma P, Gadi B R. (2014). Effect of fluoride and salicylic acid on seedling growth and biochemical parameters of watermelon (Citrullus lanatus). Fluoride.47(1):49-55.

Rao A V B, Kumar K A, Nagalaksmamma K, Vidyunmala. (2013). Effect of fluoride on protein profiles in two cultivars of mulberry leaves, Journal of Agriculture and Environment Sciences. 13, 957-60.

Sabal. D., Khan T L and Saxena R.(2006). Effect of sodium fluoride on cluster bean (Cyamopsis tetragonoloba) seed germination and seedling growth. 
Fluoride 39(3), 228.

Saini , P., Khan S, Baunthiyal and Sharma V.(2013). Effects of fluoride on germination, early growth and antioxidant enzyme activities of legume plant species Prosopis juliflora, Journal of Environmental Biology, 34(2), 205-209.

Sethy, S K., Ghosh S. (2013). Effect of heavy metals on germination of seeds, Journal of Natural Science, Biology and Medicine, Pp. 272-275.

Singh U P., RanaYashu B, Sodani R and Srivastava J P. (2017). Effect of elevated fluoride levels on morph-physiological parameters of wheat and barley, Journal of Pharmacognosy and Phytochemistry.6(6), 2245-2248.

Śnioszek M., Telesiński A, Smolik B and Zakrzewska H. (2009). Possibilities of using clay minerals to reduce fluorine effects on activity of phenolic metabolism selected enzymes in soil and pea and spring wheat plants Pierwiastki, środowisko i życieczłowieka, K. Pasternak (ed.), Wyd. System-Graf, Lublin, 344-356.

Sodani R, (2018). Morpho physiological and biochemical Responses of wheat( Triticum aestivum L.) to Flouride Toxicity. BHU, IAS, Varanasi U.P. (PhD Thesis).
Szostek R, Ciećko Z. (2017). Effect of soil contamination with fluorine on the yield and content of nitrogen forms in the biomass of crops. Environmental Science and Pollution Research, 24(9):85888601.

Wang S Y, Jiao H J, Faust M. (1991).Changes in the activities of catalase, peroxidase and polyphenol oxidase in apple buds during bud break induced by thidiazuron, Journal of Plant Growth Regulator10(14), 33-39.

Wang W, Vinocur B, Shoseyov O,AltmanA.(2004). Role of plant heatshock proteins and molecular chaperones in the abiotic stress response. Trends in Plant Science, 9(5), 244-252.

Weinstein L H, Davison A. (2004). Fluorides in the environment: effects on plants and animals. CABI.

Yamazoe F. (1962). Symptoms and mechanism of injury to crops exposed to Hydrogen fluoride. Bull. National Institute Agriculture Science, Section B. No. 12, $1-125$.

Yang S F, Miller G W. (1963). Biochemical studies on the effect of fluoride on higher plants. I. Metabolism of Carbohydrates, Organic acids and Amino acids. Biochemistry Journal, 88, 505-509.

\section{How to cite this article:}

Uday Pratap Singh, Bhudeo Rana Yashu, Sanjay Kumar and Srivastava, J. P. 2020. Biochemical Responses of Elevated Level of Fluoride in Nutrient Medium on Wheat and Barley. Int.J.Curr.Microbiol.App.Sci. 9(02): 3116-3123. doi: https://doi.org/10.20546/ijcmas.2020.902.360 